\title{
Ambiguous goals, uneven implementation - how immigration offices shape internal immigration control in Germany
}

\author{
Caroline Schultz ${ }^{1,2}$
}

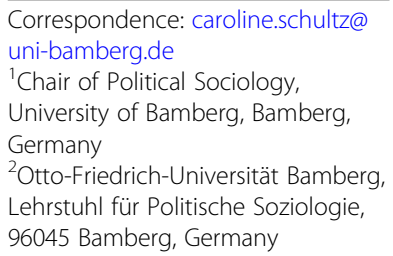

\begin{abstract}
This paper investigates regional variation in migration policy implementation, focusing specifically on the underexplored role of policy ambiguity. It chooses a salient case study of internal migration control implementation: the application of labour market access policies for migrants with precarious legal status in German municipal immigration offices. Studying the implementation approaches of eleven offices within one Land by means of semi-structured interviews with senior officials, the research design allows for drawing inter-agency and inter-policy comparisons. The data provides empirical evidence for the claim that the more conflictive and hence ambiguous a policy, the more importance can be placed on local determinants of implementation. Different logics (economic welfare and regulatory control logic) legitimizing more restrictive or expansive implementation are identified and linked to the broader migration policy context. Moreover, the difficult task of officials to determine applicants' identity clarification efforts - a condition for receiving a work permit - serves as basis for conceptually distinguishing between collective and individual discretion of street-level bureaucrats.

Keywords: Asylum seekers, Precarious legal status, Labour market integration, Migration control, Policy implementation, Street-level bureaucracy
\end{abstract}

\section{Introduction}

Scholarly knowledge about the design and effects of immigration policies has advanced substantially recently, but "[a] final missing piece of our puzzle is the implementation processes" (Helbling \& Leblang, 2018, p. 18). The aim of this paper is to systematically explore regional variation in migration policy implementation and investigate the role of an explanatory factor not sufficiently covered by existing literature (Sætren \& Hupe, 2018): the role of the level of ambiguity ${ }^{1}$ inherent in the regulation itself. It chooses a case study of internal migration control implementation, as states control immigration not only at or outside their borders, but also internally (Brochmann, 1999), and it is especially the implementation of internal migration control that remains understudied (Eule, 2018). This is surprising given that street-level bureaucrats (Lipsky, 2010) regulate access to rights and resources for non-citizens.

\footnotetext{
${ }^{1}$ Ambiguity here refers to the "[c]apability of being understood in two or more ways" (OED Online, 2019).
}

(c) The Author(s). 2020 Open Access This article is distributed under the terms of the Creative Commons Attribution 4.0 International License (http://creativecommons.org/licenses/by/4.0/), which permits unrestricted use, distribution, and reproduction in any medium, provided you give appropriate credit to the original author(s) and the source, provide a link to the Creative Commons license, and indicate if changes were made. 
Germany is an apt case for this investigation: First, it hosts a relatively high number of migrants with precarious legal status, i.e. non-citizens residing in the country who hold few rights and enjoy limited opportunities to advance to a more secure residence status (Gibney, 2009). Migrants in such a precarious position can be found in many countries (e.g. Nimführ \& Sesay, 2019). In Germany, both asylum seekers and 'tolerated' persons are migrants with precarious legal status. While asylum seekers receive a temporary residence permit for the time that their asylum application is being processed (Aufenthaltsgestattung), 'tolerated' persons, while also known to state authorities, are legally obligated to leave the country. A 'toleration' document (Duldung) designates the temporary suspension of deportation for persons without protection status and residence title whose return to the origin country can for different reasons not be enforced. ${ }^{2}$ This 'deportation gap' persists throughout Europe (EU Fundamental Rights Agency, 2011; Rosenberger \& Küffner, 2016).

Second, Germany recently selectively liberalized labour market access policies for migrants with precarious legal status (see e.g. Schammann, 2017). In particular, the recent introduction of the so-called vocational toleration (Ausbildungsduldung) can be regarded a paradigm shift in German immigration law, granting persons in the precarious legal status of 'toleration' the possibility to get on a path to regular residence for the purpose of employment. This means that what is at stake in the decision of streetlevel bureaucrats whether or not to grant a work permit is the establishment of legal rights to remain.

Third, Germany's institutional setting provides a relatively high autonomy for immigration offices in exercising internal immigration control. Several sources indicate that the administrative application of work permit issuing varies regionally to a significant extent (Breidenbach, 2017a; OECD, 2017; Schreyer \& Bauer, 2014). This regional variation arguably violates a core principle of the liberal state, namely the principle of equality of treatment and fairness. ${ }^{3}$ The issue is especially salient due to the well-researched socio-political and individual importance of labour market integration and the prospect of 'earning' residence rights via employment.

What determines how migration policies are implemented? Studies have pointed to institutional- and individual-level factors (see e.g. Alpes \& Spire, 2014; Ellermann, 2009; Eule, 2014). ${ }^{4}$ Some scholars have emphasized that the very ideologies that drive or inform policy-making shape administrative behaviour (Hall, 2010; Pratt, 2005; Satzewich, 2013). This latter link is further explored here, as the interrelationship between policy design and implementation constitutes an often neglected issue in implementation research (cf. Sætren \& Hupe, 2018). Most of the few existing studies on migration policy implementation are of explorative character, providing important insights for theory development. Few studies (e.g. Ellermann, 2009) test hypotheses on the underlying mechanisms of

\footnotetext{
${ }^{2}$ At the end of 2018, 296.060 persons with asylum decision pending and 180.124 'tolerated' persons lived in Germany (publication of the German Parliament no. 19/8258; stock figures from 31/12/2018). Similar legal constructs exist in several European countries (EU Fundamental Rights Agency, 2011).

${ }^{3}$ In this paper, a 'liberal state' is understood to be a constitutional state built on the core principles of individual liberty and the equal moral worth of people (cf. Hampshire, 2013).

${ }^{4}$ For an overview of earlier studies, see Borkert and Caponio (2010, p. 20).
} 
implementation variation. Schammann (2015) studies the implementation of the Asylum Seekers' Benefits Law in two German municipalities. Based on the theoretical considerations of Matland (1995) that assume greater implementation variation the more ambiguous and conflictive the policy, he finds that the type of implementation practice depends on the dominant local interpretation of the policy goal. However, in contrast to the here presented study, his research design does not allow for testing Matland's ambiguity-conflict-framework itself, as it focuses on one regulation only.

This paper makes two main contributions: first, its research design based primarily on semi-structured interviews with senior immigration officials in one German Land allows applying Matland's framework to a migration policy implementation context suitable for inter-agency and inter-policy comparisons. It thus provides empirical evidence for the hypothesis that under conditions of high policy goal ambiguity implementation varies considerably more than under conditions of low ambiguity. Second, it goes beyond the original Matland framework by conceptualizing different logics driving internal migration policy-making, i.e. economic welfare and regulatory control logic, and tracing how these logics (re)appear in implementation. While the paper cannot make causal claims as to why certain offices employ one or the other logic, it provides insight into a range of potential explanatory variables. It thus contributes to the still mostly explorative literature on internal migration control implementation by showing that the context of policy-making also matters for its implementation, a factor which has remained underexplored in the literature. Distinguishing between individual and collective discretion, the paper also generates new starting points for consecutive research in this field.

The paper is structured as follows: I begin with explaining the methodology. Next, relevant recent legislative changes in German internal migration control are analyzed. Thereafter, the variation in implementation approaches found in the case study is illustrated. Based on this, I subsequently identify two types of logics guiding internal immigration control, i.e. economic welfare and regulatory control logic, and demonstrate how the first is connected to more liberal and the latter to more restrictive implementation approaches. Lastly, I take the issue of identity clarification as an example to differentiate between individual and collective discretion in policy implementation. The final section concludes.

\section{Methodology}

The comparative approach of this study is a multidimensional one: it compares policies and decrees targeting two migrant groups (asylum seekers and 'tolerated' persons), and the implementation approaches of immigration offices toward these two groups. It thus combines an inter-group and inter-office comparison.

First, to assess the level of conflict and ambiguity of regulations regarding a) asylum seekers' and b) 'tolerated' persons' access to employment and vocational training, a thorough document analysis was undertaken, including relevant publications of the German Parliament, the Federal Ministry of the Interior and Länder ministries. 
Second, the operationalization of the dependent variable - restrictiveness of local implementation - relies on interview data. ${ }^{5}$ To begin with, nine explorative expert interviews on Länder approaches and inter-Länder regional variation confirmed that there was considerable variation on the dependent variable. While the federal government has the rule-making authority in immigration law, the Länder are in charge of overseeing its application by the immigration offices. The interior ministries of the Länder can issue decrees interpreting federal law, which are binding for all immigration offices within their jurisdiction, but may be trumped by courts in case of appeal. To control for the possibility that Länder government involvement has an impact on offices' implementation approach and thus confounds the analysis, one Land was chosen and the approaches of immigration offices within it compared (most-similar-systems-design) (cf. King, Keohane, \& Verba, 1994, p. 182ff). According to a compilation and comparative analysis of relevant decrees (Additional file 1: Table S1), the selected Eastern German Land can be regarded as neither generally expansive nor generally restrictive regarding labour market access of asylum seekers and 'tolerated' persons.

In October and November 2017, eleven semi-structured interviews (Rubin \& Rubin, 2012) were conducted face-to-face with heads of departments or senior officials in eleven immigration offices. ${ }^{6}$ Most department heads reported to be closely involved in day-to-day affairs at their office. In two offices, each work permit case comes through their own hands, i.e. they decide based on what their caseworkers prepared. All department heads said they convened regular (some daily) meetings with caseworkers to discuss general procedures and individual cases. At the latest, they get involved in work permit cases once complications arise, such as appeal procedures. Confidentiality was ensured to interviewees; therefore the exact places of research are not disclosed. In addition to open questions about the importance of and the procedures related to work permit applications at their offices, interviewees were asked to describe recent cases, as narratives are known to reveal more than directly asking respondents about abstract general explanations (Mosley, 2013). ${ }^{7}$ Moreover, they were asked specifically how relevant indeterminate legal terms were defined locally. ${ }^{8}$ Interviews were recorded, transcribed and then coded using a mixed approach, applying both theory-derived pregiven and open codes generated in the process (cf. Campbell, Quincy, Osserman, \& Pedersen, 2013). Quotations were translated into English by the author. To increase validity, interview data on the restrictiveness of the offices' implementation approach was later cross-checked with information from background interviews with five external experts on labour market integration of asylum seekers and 'tolerated' persons in the respective Land. These background interviews largely confirmed my previous analysis,

\footnotetext{
${ }^{5}$ As decisions of immigration offices on work permits are not systematically and centrally recorded (OECD, 2017, cf. also publication of the German Parliament no. 18/13329), it is not possible to calculate the rejection rate to use as a proxy for restrictiveness. The administrative act does not even have to be carried out in writing unless requested (Bender \& Bethke, 2018). Rejection rates are also difficult to interpret because applications might be withdrawn after an initial consultation. Aggregate data from the federal employment agency on work permit approvals cannot suffice to explain variation in the processing of work permit applications by immigration offices, as not all applications are being forwarded.

${ }^{6}$ Most interviews were one-on-one. In two cases (D3, D8; Table 2), the main interviewee insisted on having staff members participate.

${ }^{7}$ Interview guidelines are available from the author upon request.

${ }^{8}$ For example, immigration officials were asked how the term 'measures to terminate a residence' was defined at their local office, answers were grouped and coded as restrictive, restrictive-intermediate, intermediate or expansive (see below).
} 
supporting the idea that senior officials' accounts can be taken as an indication for how their respective office generally operates.

This research design allows for the identification of links between the characteristics of the policies in question and the type of implementation. Nonetheless, it is indispensable to highlight the limitations of the approach: as qualitative research, it is not generalizable beyond its specific context; yet providing context-sensitive insights into the field of internal immigration control - to which research access is not easily acquired - may help advance scholarship on the study of migration policies.

\section{Conflictive legislative changes and policy ambiguity}

It was quite interesting to observe how the obstacles were taken down. You could see, like an onion that is being peeled and at some point there was only a tiny little bit left. (D2).

As one of the immigration officials interviewed described here, since 2009, and more thoroughly 2014, several legislative changes have facilitated labour market access of asylum seekers and 'tolerated' persons in Germany (see i.a. OECD, 2017; Schreyer, Bauer, \& Kohn, 2015). This development was paralleled by a number of more restrictive policy changes, primarily with the aim of facilitating return of rejected asylum seekers (Will, 2018). The objective of granting earlier access to the labour market was to enable asylum seekers and 'tolerated' persons to support themselves more rapidly rather than remaining dependent on benefits (publication of the German Parliament no. 18/1528). The most recent reform ${ }^{9}$ was the Integration Act of August 2016, which introduced the so-called vocational toleration (Ausbildungsduldung) that was long demanded by employer organizations: accordingly, persons who take up vocational training are entitled to receive a toleration for the duration of the training (typically 3 years), and a further toleration of 6 months to look for a job after successful completion of the training. If employment is found, they receive a residence permit for 2 years. The reform is to be seen within larger developments for regularization of those 'tolerated' persons who through no fault of their own could not be deported, which had already set in with the Immigration Act of 2005 (cf. Geiger, 2016, pp. 39-42). ${ }^{10}$ The vocational toleration's novelty lies in the timing: immediately after a negative asylum decision, a path towards a right to remain can set in; it is thus a "special form of legalization" (Thym, 2016a, p. 251, own translation). Nonetheless, the Federal Government emphasizes that even a vocational toleration "legally only effects the suspension of deportation" (publication of the German Parliament no. 18/13329, own translation). The legislator's message on the regulation is thus deeply conflictive (Thym, 2016a), which can be a source of frustration for street-level bureaucrats having to implement it:

They [the government] sell something, which is only a half measure and in the end it is the offices at the bottom that are beaten up, to put it crudely, because we will be

\footnotetext{
${ }^{9}$ This paper considers only the regulations and decrees up to the time that the fieldwork was conducted (October-December 2017).

${ }^{10}$ The introduction of $\$ 18 \mathrm{a}$ and $\$ 25 \mathrm{a}$ Residence Act that allow granting residence titles to young 'wellintegrated' 'tolerated' persons in 2009 and 2011, respectively, are further examples of what Schammann (2017) calls meritocratic elements in migration politics (and one could add the later introduced $\$ 25 \mathrm{~b}$ here).
} 
seen as the prohibiting ones again. [...] And that is where the wangling starts, what do we want, do we want them out or do we not want them out? We need to have a position on this. We don't have such a position. All we have is half measures. (D1).

Policy ambiguity such as this remains an underexplored factor in research on migration policy implementation. This is somewhat astonishing, as the concept constitutes a major building block of the street level bureaucracy literature (Brodkin, 2012). In his seminal book, Lipsky (2010, p. 27) argues that "[g]oal expectations for the agencies in which [street-level bureaucrats] work tend to be ambiguous, vague, or conflicting". Frontline implementers have to perform a twofold task of interpretation: they need to interpret the often ambiguous law, and they need to apply it to the individual cases. This is why bureaucrats with direct client interactions in public institutions not only implement policy, but function themselves as policymakers (Lipsky, 2010).

It is an inherent feature of the policy process to have ambiguities in policies, they are the "natural consequence of gaining necessary support for the policies" (Baier, March, \& Saetren, 1986, p. 208; see also Lipsky, 2010, p. 41), especially in a coalition government (Martin \& Vanberg, 2005). Thus, "[s]tatutory mandates often are exceedingly vague" (Matland, 1995, p. 155), which also applies to the case study at hand: given the conflicts surrounding the vocational toleration's objectives, it is hardly surprising that the wording in the respective $\$ 60$ a II 4-12 of the Residence Act is not crystal-clear either. Thym (2016a, p. 250, own translation) attests the new regulation an "(outsized) complexity", originating from the fact that "competing interests have been embodied in the ramified details of regulations". An evident indication for this conflict is that the text of the draft regulation was changed in the very last minute by including that the vocational toleration is only to be granted if "concrete measures to terminate a residence are not on hand" (Breidenbach, 2017b; cf. Thym, 2016a). The interpretation of this indeterminate legal term is only one of several contested legal questions surrounding the regulation (Röder \& Wittmann, 2017). Indeterminate legal terms remain open for interpretation by implementers. According to Matland (1995), the type of implementation that likely occurs depends on the degree of ambiguity and whether the conflict present in the policy-making stage persists after a policy is adopted: in case of low conflict and low ambiguity, "administrative implementation" will occur. In highly symbolic policy fields, conflicts often remain despite of ambiguous policy formulation. In this case, "symbolic implementation" will likely occur and there will be large variation in implementation outputs (Matland, 1995, pp. 165-170). ${ }^{11}$

Migration can certainly be regarded a highly symbolic policy field, as respective regulations determine different gradients of membership of a nation-state; i.e. privileges that affect access to material and symbolic resources. Indeed, goal ambiguity is comparatively frequent in migration policies (de Haas \& Natter, 2015; Jordan, Stråth, \& Triandafyllidou, 2003; Schammann, 2015). As Eule et al. (2019, p. 86) highlight based on an ethnography on migration control in eight European countries, "[s]treet-level

\footnotetext{
${ }^{11}$ Although published more than two decades ago, according to a recent review of the literature Matland's (1995) theoretical framework is still very relevant, as it constitutes 'one of the last theoretical constructs [...] that has been launched to reconcile the top-down and bottom-up approaches in implementation research' (Sætren \& Hupe, 2018, p. 566).
} 
bureaucrats are very well aware of [...] often-opposing demands and try to place themselves and their decisions within the often-politicised context".

In the present case study, it was especially regulations granting access to economic integration for 'tolerated' persons that caused conflict in policy-making and public debate. In contrast, the work permit for asylum seekers was less conflictive, as it does not imply the same potential consequences for persons' right to remain. The conflict around 'tolerated' persons' access to work reappeared soon after the vocational toleration was introduced, when economic associations demanded more consistent (and more liberal) implementation by local immigration offices (publication of the German Parliament no. 18/13329). The Federal Ministry of the Interior (BMI) therefore issued guidance notes on \$60a Residence Act in May 2017, including detailed, albeit legally unbinding, notes on the vocational training regulations. At least seven Länder have since issued decrees of their own that add to the BMI Notes, sometimes explicitly stating that certain interpretations of the legal text are not shared (Additional file 1: Table S1). These administrative regulations constitute a legal 'nought' (Bender \& Bethke, 2018). At the time of conducting the interviews, the Land chosen as case study did not have its own decree on vocational toleration.

\section{Variation in implementation approaches}

While work permit applications were part of day-to-day work in the immigration offices visited, the relatively new vocational toleration had not been applied for in large numbers (yet) at the time of investigation. According to the Administration Department of the Land chosen as case study, from January to September 2017, 70 vocational tolerations were applied for, a little more than half of which were issued (some were still being processed). In 2016, the employment agency gave their consent for work permits in this Land in about 750 cases (> 80\% approval rate), about $90 \%$ of which for asylum seekers and the remaining 10\% for 'tolerated' persons (Statistik der Bundesagentur für Arbeit, 2017). The overall implementation setting is very dynamic, as almost all offices experienced an increase in caseload and subsequently also in staff since 2015.

Interview data confirmed variation in implementation approaches of immigration offices. The degree of this variation is minimal regarding asylum seekers' work permit applications and very pronounced regarding 'tolerated' persons, a finding later backed up by external experts. Interviewees reported that work permit applications of asylum seekers go rather smoothly:

During the asylum procedure, we don't have to check anything regarding the work permit. In principle, everyone who applies for it and can present an employment contract and the employment agency confirms it gets the work permit, always together with the notice that things can change once the asylum procedure is completed. (D10).

The last sentence already points to the fact that work permit applications for rejected asylum seekers ('tolerated') are much more contentious. This went to the point where in one district, the head administrator (who also holds political office) had issued an internal instruction note stating that persons who are employed are generally not to be deported - a very expansive interpretation of the law: 
He [the Landrat] is very active in this; he himself promotes the idea to hire refugees in the business community. The demographic change becomes more and more noticeable [...]. There is a big personal interest of the Landrat for us to become active [...]. (D9).

In another district, the (former) head of office's (Amtsleiter) stance was that work permits should never be issued for 'tolerated' persons - a very restrictive interpretation of the law:

He took the view that 'tolerated' persons should not have employment in principle, because they are obliged to leave and we don't want to make life here appealing to them [...] [S]o we had to bow to that and did basically not issue work permits for 'tolerated' persons. (D7).

Apart from these extreme cases, there was also considerable variation within the rest of the districts on handling 'tolerated' persons' work permit applications; for instance regarding the interpretation of what constitutes 'concrete measures to terminate a residence', the existence of which prohibits a vocational toleration. This is an indeterminate legal term which leaves room for interpretation or 'discretion', the notion of which shall be further explored below. Some officials already considered the criterion of 'concrete measures to terminate a residence' to be present once a deportation order is sent to the responsible agency on Land level (D3), others only after verifying that the agency has already started working on the file (D4, D8, D11), and yet others once travel documents are ready and the flight is scheduled or about to be scheduled (D1, D2, D5, D7, D10). Two interviewees answered that already sent deportation orders (if a flight is not yet scheduled) could be cancelled in case a client has secured a vocational training contract and applied for the respective toleration (D6, D9). There was also variation regarding clients' transition from the asylum seekers' permit to a toleration following a negative asylum decision regarding the timeframe and insistence that offices put in reassessing and possibly withdrawing a work permit. Besides confirming the importance of ambiguity in the legal text for implementation, this is also in line with Eule's (2014) finding that implementation outcomes are particularly diverse in those cases in which migrants have relatively insecure legal statuses.

Linking this to the policy ambiguity literature and the described context of the present case study, the following interim conclusion can be drawn: while regulations on liberalizing access to work for asylum seekers were passed relatively smoothly and have not generated much debate, the regulation on the vocational training for 'tolerated' persons abounds with ambiguity in its wording and was accompanied by conflictive discussions before, during and after its adoption. The interview data confirms that these differences have had an impact on how smoothly and consistently both policies are implemented, and hence provide empirical evidence for the soundness of Matland's framework in internal migration policy implementation.

\section{Employed logics: regulatory control vs. economic welfare}

Migration is a politicized issue and migration policies are generally conflictive (e.g. Hampshire, 2013). The conflict of objectives in internal immigration policies has been referred to as "a dilemma between migration control and integration promotion" 
(Thym, 2016a, p. 251). ${ }^{12}$ This dilemma pervades societal debates, the political arena and policy implementation. ${ }^{13}$ It can be systematically spelled out as follows: the two competing logics or justifications for action are on the one hand the regulatory control logic and on the other hand the economic welfare logic (Table 1). Both depart from different assumptions and conceptions of fairness, contain different interests, and are traceable in the implementation context.

The regulatory control logic is based on the idea that the rule of law should be consistently implemented, which implies the primary objective of residence termination of those without a right to remain. Entitlement is thus closely linked to the legal status of the person, explicitly categorizing those with and those without a right to remain. An example for clear regulatory control logic would be:

\section{A 'tolerated' person is in fact not to be integrated. There the residence is to be} terminated by law. (D3).

As social ties associated with economic integration can hinder efforts to forcefully remove a person later on (Ellermann, 2009; Gibney, 2008), the objective of residence termination trumps any potential benefits of labour market participation. Prioritizing return can be seen as 'acting tough' on migration; and access barriers to the labour market can have signaling effects both towards the 'native' population ('Your jobs will be protected against intruders') and towards potential immigrants ('There is no point in choosing the asylum route if not eligible for a protection status').

In contrast, the economic welfare logic departs from the acknowledgment that many 'tolerated' persons are effectively not deportable (cf. Rosenberger \& Küffner, 2016). The primary objective therefore is economic integration in order to minimize welfare dependence of those likely to stay, providing a pragmatic way out of the deadlock for both migrants and the state. Demands of employers in times of (projected) skills shortages and demographic ageing are meant to be met by including this population into the pool of employable people. Large-scale social exclusion and societal instability or insecurity can thereby be avoided. In the following example an official talked about a 'tolerated' young man whose first vocational training placement did not work out:

[W]e do try to place them somehow into something so that they can stay. One always says, there is a lack of skilled workers or in general of trainees in trade, so if one already has someone, then one can let him stay as well. (D6).

The main underlying conception of fairness of the economic welfare logic is meritocracy (Schammann, 2017): participating in training and the labour market, migrants with precarious legal status can 'earn' the right to remain. This is also a signaling effect to those concerned: 'If you make an effort, you can make it here.' Focus on labour market integration arguably also signals to the general public that certain migrants 'deserve' to

\footnotetext{
${ }^{12}$ These migration policy conflict lines run not only across, but also within political parties: For instance, centre-left parties are usually driven by both 'welfare state/labour market protectionism' and 'international solidarity', while centre-right parties usually seek to combine 'market liberalism' with 'value conservatism' (de Haas \& Natter, 2015, p. 4).

${ }^{13}$ Morris (2010) examines judicial cases on welfare support for asylum seekers in the UK, contrasting a 'cosmopolitan' with a 'national' paradigm in order to aid the analysis. Similarly, the conceptualization of the two logics proposed here is meant to serve as an investigative lens primarily.
} 
Table 1 The two competing logics of internal migration control

\begin{tabular}{|c|c|c|}
\hline & Regulatory control logic & Economic welfare logic \\
\hline $\begin{array}{l}\text { Assumption / point } \\
\text { of departure }\end{array}$ & $\begin{array}{l}\text { Imperative to enforce the rule of law } \\
\text { consistently }\end{array}$ & Acknowledge that barriers to deportation persist \\
\hline $\begin{array}{l}\text { Conception } \\
\text { of fairness }\end{array}$ & $\begin{array}{l}\text { Fairness as rule of law (right to } \\
\text { remain versus no right to remain) }\end{array}$ & $\begin{array}{l}\text { Meritocracy: training / working establishes } \\
\text { deservingness; Kantian: presence grants rights }\end{array}$ \\
\hline Primary objective & $\begin{array}{l}\text { Priority of residence termination for } \\
\text { those without a legal right to remain }\end{array}$ & $\begin{array}{l}\text { Priority of integration to minimize burden on } \\
\text { social security systems }\end{array}$ \\
\hline $\begin{array}{l}\text { Secondary } \\
\text { objective(s) }\end{array}$ & $\begin{array}{l}\text { Avoid integration to not counteract } \\
\text { priority of residence termination }\end{array}$ & $\begin{array}{l}\text { Meet employer demands (skills shortages), avoid } \\
\text { large-scale social exclusion (security aspect) }\end{array}$ \\
\hline $\begin{array}{l}\text { Signalling effect(s) } \\
\text { to the public }\end{array}$ & $\begin{array}{l}\text { Acting 'tough' on migration, } \\
\text { protecting 'native' jobs }\end{array}$ & Migrants contribute to social security systems \\
\hline $\begin{array}{l}\text { Signalling effect } \\
\text { to (potential) migrants }\end{array}$ & $\begin{array}{l}\text { No incentive: access to the labour } \\
\text { market is difficult }\end{array}$ & $\begin{array}{l}\text { Cooperation rewarded with rights to integrate / } \\
\text { remain }\end{array}$ \\
\hline
\end{tabular}

Source: own compilation

be received as productive members of society (on the link to deservingness, see e.g. Chauvin \& Garcés-Mascareñas, 2014; Gonzales, Sigona, \& Burciaga, 2016).

Table 2 provides an overview of the offices' implementation approaches vis-à-vis the two target groups and the logic predominantly employed by the respective interviewee. It demonstrates that while some officials referred solely to reasons grouped under the economic welfare logic when describing their handling of work permit applications, others referred to both logics, and some exclusively expressed their view that they were to prioritize return over integration (Table 2, last column). Moreover, the data provides some indication for regulatory control logic being linked with more restrictive, and economic welfare logic being linked with more expansive implementation approaches in the case of 'tolerated' persons.

It is beyond the scope of this paper to provide a clear answer as to why interviewees employ which logic. Looking at potential explanatory variables, the examples given in the previous chapter highlight the obviously influential role of superiors, in line with

Table 2 Implementation approaches according to policies and employed logics, by level of restrictiveness re: 'tolerated' persons

\begin{tabular}{lllll}
\hline District / city & \multicolumn{2}{l}{ Implementation approaches } & Employed logics \\
\cline { 2 - 4 } & Self-description & Re: asylum seekers & Re: 'tolerated' persons & \\
\hline D6 & expansive & expansive & expansive & $\mathrm{econ}$ \\
D9 & expansive & expansive & expansive & $\mathrm{econ}$ \\
D10 & - & expansive & intermediate & $\mathrm{econ}$ \\
D1 & - & - & intermediate & $\mathrm{reg}$ \\
D4 & - & expansive & intermediate & $\mathrm{econ} / \mathrm{reg}$ \\
D5 & - & expansive & intermediate & $\mathrm{econ} / \mathrm{reg}$ \\
D7 & restrictive / expansive & expansive & intermediate-restrictive & $\mathrm{econ} / \mathrm{reg}$ \\
D2 & restrictive & expansive & intermediate-restrictive & $\mathrm{econ} / \mathrm{reg}$ \\
D11 & expansive & intermediate-restrictive & intermediate-restrictive & $\mathrm{econ}$ \\
D3 & restrictive & expansive & restrictive & $\mathrm{reg}$ \\
D8 & - & intermediate & restrictive & $\mathrm{reg}$ \\
\hline
\end{tabular}

Note: Interviewees were asked about their self-description indirectly, i.e. how they evaluate the practices of their office in comparison with others. If interviewees remarked about their practices as relatively 'restrictive' or 'expansive' on other occasions during the interview, this was coded as well. About half of interviewees did not disclose a self-description 
earlier research (Ellermann, 2009; Eule, 2014; Schreyer \& Bauer, 2014). Their specific political affiliation, gender or local labour market factors have not been found to convincingly explain variation in the case study context, however. ${ }^{14}$ External pressure by employers or volunteer groups may have an impact on implementation, both leading immigration officials to reconsider cases (D5), but also to heightened suspicion, if e.g. an applicant tells the office that their lawyer advised them not to present any identification documents (D2). As an internal explanatory factor, pragmatism has been shown to play an important role in the daily work of immigration officials (Eule, 2018). Applied to the case study, pragmatism, as an inherent component of economic welfare logic, can result in a quite generous application of ambiguous policies:

We are, in the particular cases, also a little bit past the law [...]. When someone comes with a vocational training contract, [...] theoretically I could have put the Kosovar Albanian on the plane. We didn't do that. [...] We were a bit generous there; [...] everything else would have been nonsense. Why put yourself under such stress; and then all the volunteers who have maybe made an effort to place someone in a training company. (D6).

This quotation is remarkable in two ways: it shows how officials may use their room for maneuver in ways that can be completely detached from the law (Eule et al., 2019): Kosovo is actually one of the by law designated 'safe countries of origin', and hence nationals from there are legally excluded from the possibility of obtaining a vocational toleration. Pragmatism in conjunction with the presence of volunteers or vocal employers may, however, lead to this restriction being discarded.

In reality, the conflict of objectives is more complex. For instance, there is an important temporal dimension, where one objective can gradually replace the other with the passing of time, when it becomes clear that return is not viable through no fault of the person concerned (SVR, 2017; Thym, 2016b). Moreover, there may be an ethnocultural dimension running transversely to the two logics. Recent literature has emphasized the blurring of the economic and the ethnocultural in migration politics (e.g. Bonjour \& Duyvendak, 2018; Chauvin, Garcés-Mascareñas, \& Kraler, 2013). In the presented framework, ethnocultural considerations rather seem to underlie a regulatory control logic in which exclusion is justified by strict appliance of the law. The following quotation shows how 'the foreigner' was conceptualized as the uncivilized 'other' by the official, who talked about an apartment provided for one of their clients by the district:

They also have to come to grips with our culture, and that is a very important aspect. And we do realize how difficult it is for the foreign citizens, how do I put this now? It is difficult to get them used to our living conditions. What for us is normal, is typical or is also German then. [...] But when you are opening an apartment like that, and it

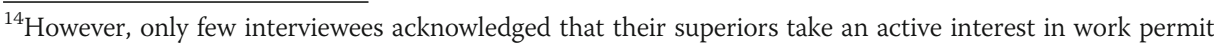
applications. The political party of the head administrator does not seem too decisive: among expansive and intermediate cases, there are members of the CDU, the SPD and Die Linke; more restrictive districts are headed not by SPD and Die Linke members, though, but by CDU or FDP party members. The success of the far-right party AfD does not seem relevant. For instance, one of the expansive cases had the highest share of second votes for AfD in the 2017 Parliamentary Elections of all the districts in the sample (>24\%). There also does not seem to be a clear gender effect.
} 
is full of [...] garbage. Where you say, you feel ashamed. And then you know that these persons do not want to embrace this in actuality. They come here and live their lives, and they have of course lived another live [before], which is hard to imagine for us. Also lived with another hardship, not only because they have found the way to us, be it via sea or land, they have a completely different expectation, which is not similar to ours. (D8).

The implementation approach of the office said official directed was categorized as restrictive in terms of 'tolerated' persons, and intermediate regarding asylum seekers, which makes it one of the most restrictive offices studied regarding labour market access. Contrary to this, and maybe at the opposite end of the spectrum, another official described the opportunity to get to know "the cultures and interesting people" as an asset of their job (D9) - their immigration office was found to be one of those with the most expansive approach regarding labour market access of migrants with precarious legal status (Table 2).

In any case, the simplification of the two logics introduced here was meant to describe the general conflict lines in order to use them as a heuristic schema in the analysis. The crucial point is: "Implementation [...] is a continuation of the social and political environment in which policy decisions were taken" (Jordan et al., 2003, p. 211). For instance, Western norms of love marriage shape visa officials' decisionmaking on family reunification cases (Scheel, 2017). In the present case study of work permit applications of migrants with precarious legal status, immigration officials operate in an area of conflict between residence termination and regularization or integration. Just as both logics co-existed in the phase of policy-making, they were also found to be present in the phase of policy implementation. The interview data indicates that which one of the two dominates actors' decisions plays a role for the restrictiveness of the implementation approach chosen.

\section{Collective and individual discretion in identity clarification}

Returning to the image of the peeled onion, amidst increasing liberalization of labour market access for asylum seekers and those without a right to remain, one of the remaining obstacles is that applicants have an 'obligation to cooperate' (Mitwirkungspflicht) in obtaining identity documents. Cooperation with return is a central tool in migration control in Europe (Rosenberger \& Koppes, 2018). According to the immigration officials interviewed, non-compliance with the obligation to cooperate constitutes the main reason for denying work permits and vocational training for 'tolerated' persons. ${ }^{15}$ The right to work has become a tool in asylum policy and migration control (Valenta \& Thorshaug, 2013), and here the importance of discretion comes to the fore. The issue of identity clarification shall be taken as an example to elaborate on the concept of discretion in policy implementation, proposing to distinguish between collective and individual discretion.

Discretion constitutes a central analytical concept in the policy implementation literature (Lipsky, 2010). The term 'discretion' is, however, used in various ways in different

\footnotetext{
${ }^{15}$ This does not apply to asylum seekers, which is an important reason for asylum seekers' work permit applications being less controversial than the ones issued by 'tolerated' persons. Demanding identification of asylum seekers is exceptional.
} 
scholarly disciplines (for an overview, see Eule et al., 2019, pp. 84-90). In accordance with Eule et al. (2019, p. 87), I understand discretion in policy implementation as "both necessary and potentially problematic". While it is impossible to design laws in a way that can be unequivocally applied to every individual case, discretion can be problematic in that it produces outcomes not consistent with general liberal norms of fairness and legal certainty. From the literature it is clear that there is wide scope for discretionary decision-making in migration policy implementation (e.g. Alpes \& Spire, 2014; Pratt, 2010; Salter, 2007).

While discretion has originally been conceptualized primarily as exercised by individuals, the policy implementation literature recently started focusing on its collective dimension (Rutz \& du Bont, 2020). Based on the interview data, and supplementing previous studies, I illustrate here that one can conceptually distinguish between collective and individual discretion in internal migration control implementation. Collective discretion then denotes general interpretations of ambiguous legal texts that are taken by superiors or jointly by the officials for the entirety of an office:

Where there is room for discretion [...] one has to execute discretion; that is you say 'as district $X$, as a baseline we do it this way', which might in the nuance deviate from other immigration offices. [...] The last decree, you have to issue yourself, so to speak. So, we have to reach an agreement here [at the office] on how we apply [the regulation]. (D5).

The example of identity clarification provides insights into how offices interpret certain aspects of ambiguous regulations for their entire agency, defining in broad lines how to implement these locally. For instance, one office reported using internally drafted guidelines to determine the specific demands of cooperation in identity clarification for specific countries of origin (D3). Another interviewee explained that in their office, they distinguished between looser demands in identity clarification for asylum seekers' work permits and stronger ones for the more momentous issue of vocational toleration (D2). Applicants with a toleration status often find themselves in a deadlock: They are worried they could be deported once they present identification documents, but non-cooperation in obtaining them is a reason for work permit refusal. One official mentioned that at their office they came up with a "creative solution" to this deadlock, a type of condition subsequent (D10, similarly D2).

Similar to the term 'concrete measures to terminate a residence', there is no clear rule how to interpret if someone's efforts to obtain a passport are sufficient, i.e. whether cooperation can be reasonably expected (Zumutbarkeit). This provides for an example of individual discretion, i.e. for how street-level bureaucrats deal with individual cases:

This is where the scope for interpretation starts, where you say: 'well, it is not his fault; the embassy hasn't given him an appointment'. Yes, those are the diverse minor details that provoke discretion or contradictions. (D5).

Several officials mentioned identity clarification to be a source of uncertainty in their work and express that they would like to have clearer instructions on how 
to handle it (D1, D4, D7, D8, D9); although these would be difficult to draft due to dynamically changing levels of cooperation by origin countries. Others remarked that they enjoyed the leeway that discretion provides them with (D2), or, to the contrary, hid behind the view that they would not have any room for discretion at all (D3). Regarding the vocational toleration, officials claimed they would not deport an applicant if they obtained a passport after the person had applied, but it would be hard for applicants to trust the immigration office (D1, D2, D3, D8, D9, D10, D11). The distrust is mutual, however (cf. Griffiths, 2012): for instance, officials (D5, D6, D7) assumed that applicants did have identity documents:

With the black Africans it is even more difficult [than with nationals X]. Usually they have already been here for a comparatively long time and in parts they come to me and say: 'I don't have anything [identity documents], I don't know anyone [in the country of origin], I'm not in touch with my sister anymore', but she lives there still, and well, what shall I do with them. I cannot blame them. Usually it happens then, that is the crux, that when they want to marry or have a child, a German one, then all of a sudden the passport magically appears, yes. (D7).

This is in line with descriptions of a "culture of suspicion" present at different sites of migration control implementation (Alpes \& Spire, 2014, p. 268; cf. also Dahlvik, 2017; Eule et al., 2019; Hall, 2010; Infantino, 2016; Pratt, 2010; Salter, 2007; Scheel, 2017). Interestingly, the official's remark about 'magically appearing passports' illustrates both a certain pragmatic serenity ("I cannot blame them") in conjunction with a weakly defined ethnic group bias. In general, the interviews indicate that immigration officials' perceptions of clients' compliance with identity clarification varies according to their origin, with references made to certain nationalities, but also - in the broader description of their work - to "cultures", "traditions" and religion. This can be taken as an instance of the use of "racialized knowledges" that border officials have been shown to rely on (Pratt, 2010, p. 472). Beyond the one-off encounters at land ports of entry that Pratt (2010) analyzed, for migration officials with repeated client interaction (such as in detention centres, or, less intensively, at immigration offices), being unsure about their clients' identity seems to be a formative aspect of their work (Hall, 2010). In this regard, one interviewee directly linked identity clarification to deservingness and a meritocratic conception of fairness. As colleagues from other offices (e.g. D1, D5, D6), the official emphasized that it would be important:

[...] that I know who I am dealing with. That I really know, this is such and such and he is willing to find his way here [...]. This willingness is a really important part of integration for me. [...] One can also drop out of a training or quit a job [...], but the willingness to do this and above else the appreciation towards the country by saying, I am such and such, I am this and this person. (D10).

Interpreting an individual case against the ambiguous law, ideas of deservingness closely linked with both regulatory control and economic welfare logics seem to be 
crucial. ${ }^{16}$ It can only be hypothesized here that deservingness perceptions might be linked especially to how individual discretion is being exercised.

Again an instance of collective discretion, some offices actively sought to use employers as allies in identity clarification: as the companies have an interest in the person remaining, they can help explain to them the importance of cooperating with the authorities (e.g. D9, D11). For example, in a district employing strong economic welfare logic, the immigration office even reached out to companies employing asylum seekers whose claim had finally been rejected:

\section{Then we wait [...] and see whether something [identity document] is being presented} or not. [...] We then [...] write to the companies and say: Dear company XY, you have employed Mr. XY, but he is obliged to leave and has to present his passport, do influence him a little bit; we guarantee you that [...] he won't be deported once the passport is presented. (D9).

In summary, identity clarification, as both condition for obtaining a work permit and necessity to make migrants with precarious legal status deportable, epitomizes the level and significance of policy goal ambiguity in the implementation of internal migration control. The issue serves as an example to elaborate on the concept of discretion in policy implementation by distinguishing between collective and individual discretion.

\section{Conclusion}

This paper explored the role of an understudied part of the policy implementation puzzle, namely policy goal ambiguity. It thereby sought to analyze more in-depth the link between the ideologies that drive policy-making and the application of those policies by street-level bureaucrats. An especially salient case of internal immigration control was investigated: immigration offices' handling of work permit applications for migrants with precarious status in Germany. The empirical case of labour market access regulations for those who do not (yet) have a legal right to remain provides new perspectives on the wider migration policies literature, showcasing the tension between residence termination and economic welfare objectives as a policy dilemma of all levels of the liberal state. In a highly conflictive policy field such as migration, ambiguous policies are likely the rules rather than the exception; the question of how this impacts implementation has however not been systematically tackled yet.

Focusing on two groups of migrants with precarious legal status in the same implementation context, the research design allowed for analyzing the role of policy goal ambiguity in a comparative way. In combination with document and policy analysis, semistructured interviews with senior officials in eleven municipal immigration offices in one German Land complemented by expert background interviews provide the basis for the following conclusions:

First, there is variation in the implementation approaches of German immigration offices even within one Land. Second, the degree of this variation seems to depend upon the level of ideological conflict surrounding a policy and the related ambiguity of its phrasing, supporting a key assumption of Matland's (1995) theoretical framework:

\footnotetext{
${ }^{16}$ This is in line with the burgeoning literature on the link of migration policies and deservingness (cf. e.g. Chauvin \& Garcés-Mascareñas, 2014; Gonzales et al., 2016).
} 
variation was found to be minimal regarding asylum seekers' work permit applications and very pronounced regarding persons with the even more precarious toleration status. For the latter, the dilemma between residence termination and integration is much more salient, as their asylum application has already been finally rejected and employment would significantly improve their chances of a right to remain in the future. Third, immigration officials as street-level bureaucrats need to interpret the ambiguous law, and they do not do this in a vacuum, but seem to employ larger contextual policy logics that correlate with their office's implementation approach. The data indicate that those adhering primarily to the prioritization of strict legal rules tended to show a more restrictive, and those employing more pragmatic, economic welfare oriented logic a more expansive interpretation of the law's objectives. Fourth, identity clarification proved to be a recurring topic in migration policy implementation, and served as an example to distinguish between collective and individual discretion. Officials are in the paradoxical situation of having to claim identity documents from 'tolerated' work permit applicants who they would have to deport once they obtain those documents. Fifth, and linked to the previous point, when interpreting an individual case against the ambiguous law, ideas of deservingness that relate to the meritocratic conception of fairness seem to be present.

While not generalizable beyond its specific context, this paper took a first step in investigating how goal ambiguity in internal immigration control (as a subfield of migration policies) plays out in implementation, in a context of relatively high bureaucratic autonomy. Future research on the still often neglected interrelationship between policy design and implementation (cf. Sætren \& Hupe, 2018) could focus more on other potential explanatory variables not explored in-depth in the present paper, e.g. external pressure on implementers. From a policy recommendations perspective, the findings call for clearer communication and contextualization of policy goals, in order to minimize existing regional variation: assuming state principles of equal opportunities and fairness, one's chances of obtaining a work permit and, more importantly, future residence rights should not depend on the specific orientation of one's local immigration office.

\section{Supplementary information}

Supplementary information accompanies this paper at https://doi.org/10.1186/s40878-019-0164-0.

Additional file 1: Länder decrees on labour market access for asylum seekers and tolerated persons, 2016/2017 (territorial Länder only)

Abbreviations

BMI: Federal Ministry of the Interior; Econ: Economic welfare logic; OECD: Organization for Economic Cooperation and Development; OED: Oxford English Dictionary; Reg: Regulatory control logic

\section{Acknowledgements}

First and foremost, I would like to thank the interviewees who made this research possible. Moreover, I am grateful to Marc Helbling, Tobias Eule, Antje Ellermann, Teresa Büchsel, Katerina Glyniadaki, Holger Kolb, Nora Ratzmann, Mouna Maaroufi as well as seminar and conference participants at the University of Bamberg, the IES Research Colloquium at the University of British Columbia, the IMISCOE Annual Conference 2018 and the ECPR General Conference 2018 for providing valuable comments on the research design and previous versions of this article; and to the anonymous reviewers for helpful comments and suggestions.

Author's contributions

CS is the single author, all contributions are by her. The author read and approved the final manuscript. 
Availability of data and materials

The dataset generated for this study is not publicly available in order to protect the research participants.

\section{Competing interests}

The author declares that she has no competing interests.

\section{Received: 11 July 2019 Accepted: 14 October 2019}

Published online: 17 February 2020

\section{References}

Alpes, M. J., \& Spire, A. (2014). Dealing with law in migration control: The powers of street-level bureaucrats at French consulates. Social \& Legal Studies, 23, 261-274. https://doi.org/10.1177/0964663913510927.

Baier, V. E., March, J. G., \& Saetren, H. (1986). Implementation and ambiguity. Scandinavian Journal of Management Studies, 2(3-4), 197-212. https://doi.org/10.1016/0281-7527(86)90016-2.

Bender, D., \& Bethke, M. (2018). Die Ausbildungsduldung nach $\$ 60 a$ Abs.2 S.4ff. Aufenth $\mathrm{im}$ föderalen und gewaltengeteilten Rechtsstaat, Vortrag, 27.01.2018. Hohenheim [The vocational toleration according to $\$ 60 a$ Abs. 2 S. 4ff. Residence Act in the federal and power-separated constitutional state, presentation, 27.01.2018. Hohenheim].

Bonjour, S., \& Duyvendak, J. W. (2018). The "migrant with poor prospects": Racialized intersections of class and culture in Dutch civic integration debates. Ethnic and Racial Studies, 41(5), 882-900. https://doi.org/10.1080/01419870.2017.1339897.

Borkert, M., \& Caponio, T. (2010). Introduction: The local dimension of migration policymaking. In T. Caponio, \& M. Borkert (Eds.), The local dimension of migration policymaking, (pp. 9-32). Amsterdam: Amsterdam University Press. https://doi.org/ $10.5117 / 9789089642325$

Breidenbach, W. (2017a). Aktuelle Rechtsfragen zur Ausbildungsduldung nach $\$ 60 a$ AufenthG. Halle (Saale): Vortrag an der Universität Halle-Wittenberg [Current legal questions on the vocational toleration according to \$60a Residence Act, presentation at the University Halle-Wittenberg].

Breidenbach, W. (2017b). Flüchtlinge in Ausbildung - Manchmal kommt es auf das Kleingedruckte an [Refugees in vocational training - sometimes it's about the small print]. Mitteldeutsche Wirtschaft - Das Magazin Der IHK Halle-Dessau, Mai, (p. 34).

Brochmann, G. (1999). The mechanisms of control. In G. Brochmann, \& T. Hammar (Eds.), Mechanisms of immigration control: A comparative analysis of European regulation policies, (pp. 1-28). Oxford: Berg.

Brodkin, E. Z. (2012). Reflections on street-level bureaucracy: Past, present, and future. Public Administration Review, 72(6), 940949. https://doi.org/10.1111/j.1540-6210.2012.02657.x.

Campbell, J. L., Quincy, C., Osserman, J., \& Pedersen, O. K. (2013). Coding in-depth Semistructured interviews: Problems of unitization and Intercoder reliability and agreement. Sociological Methods and Research, 42(3), 294-320. https://doi.org/10. $1177 / 0049124113500475$.

Chauvin, S., \& Garcés-Mascareñas, B. (2014). Becoming less illegal: Deservingness frames and undocumented migrant incorporation. Sociology Compass, 8(4), 422-432. https://doi.org/10.1111/soc4.12145

Chauvin, S., Garcés-Mascareñas, B., \& Kraler, A. (2013). Working for legality: Employment and migrant regularization in Europe. International Migration, 51(6), 118-131. https://doi.org/10.1111/imig.12109.

Dahlvik, J. (2017). Asylum as construction work: Theorizing administrative practices. Migration Studies, 5(3), 369-388. https:// doi.org/10.1093/migration/mnx043.

de Haas, H., \& Natter, K. (2015). The determinants of migration policies - does the political orientation of governments matter? Oxford: IMI Working Papers, Paper 117.

Ellermann, A. (2009). States against migrants - deportation in Germany and the United States. Cambridge: Cambridge University Press.

EU Fundamental Rights Agency (2011). Fundamental rights of migrants in an irregular situation in the European Union. Vienna. https://doi.org/10.2811/31559.

Eule, T. (2014). Inside immigration law. Migration management and policy application in Germany. Abingdon: Routledge.

Eule, T. (2018). The (surprising?) nonchalance of migration control agents. Journal of Ethnic and Migration Studies, 44(16), 2780-2795. https://doi.org/10.1080/1369183X.2017.1401516

Eule, T., Borrelli, L. M., Lindberg, A., \& Wyss, A. (2019). Migrants before the law. Contested migration control in Europe. Cham: Palgrave macmillan.

Geiger, D. (2016). Handlungsfähigkeit von geduldeten Flüchtlingen. Eine empirische Studie auf der Grundlage des agencyKonzeptes [Capacities of tolerated refugees. An empirical study based on the concept of agency]. Freiburg: Springer VS. https://doi.org/10.1017/CBO9781107415324.004

Gibney, M. J. (2008). Asylum and the expansion of deportation in the United Kingdom. Government and Opposition, 43(2), 146-167. https://doi.org/10.1111/j.1477-7053.2007.00249.x.

Gibney, M. J. (2009). Precarious residents: Migration control, membership and the rights of non-citizens. New York: UNDP Human Development Reports Research Paper 2009/2010.

Gonzales, R. G., Sigona, N., \& Burciaga, E. M. (2016). Citizenship, rights, and deservingness: Introduction to the special issue. American Behavioral Scientist, 60(13), 1531-1533. https://doi.org/10.1177/0002764216664940.

Griffiths, M. (2012). Vile liars and truth distorters. Anthropology Today, 28(5), 8-12.

Hall, A. (2010). 'These people could be anyone': Fear, contempt (and empathy) in a British immigration removal Centre. Journal of Ethnic and Migration Studies, 36(6), 881-898. https://doi.org/10.1080/13691831003643330.

Hampshire, J. (2013). The politics of immigration. Contradictions of the Liberal state. Cambridge: Polity Press.

Helbling, M., \& Leblang, D. (2018). Controlling immigration? How regulations affect migration flows. European Journal of Political Research, 1-22. https://doi.org/10.1111/1475-6765.12279.

Infantino, F. (2016). State-bound visa policies and Europeanized practices. Comparing EU visa policy implementation in Morocco. Journal of Borderlands Studies, 31(2), 171-186. https://doi.org/10.1080/08865655.2016.1174603.

Jordan, B., Stråth, B., \& Triandafyllidou, A. (2003). Contextualising immigration policy implementation in Europe. Journal of Ethnic and Migration Studies, 29(2), 195-224. https://doi.org/10.1080/1369183032000079594.

King, G., Keohane, R. O., \& Verba, S. (1994). Designing social inquiry - scientific inference in qualitative research. Princeton: Princeton University Press Retrieved from papers2://publication/uuid/2A4A1670-67F1-445C-BDB4-EAE08520D016. 
Lipsky, M. (2010). Street-level bureaucracy - dilemmas of the individual in public service, 30th anniversary, (Expanded ed., ). New York: Russell Sage Foundation.

Martin, L. W., \& Vanberg, G. (2005). Coalition policymaking and legislative review. American Political Science Review, 99(1), 93-106.

Matland, R. E. (1995). Synthesizing the implementation literature: The ambiguity-conflict model of policy implementation. Journal of Public Administration Research and Theory: J-PART, 5(2), 145-174. https://doi.org/10.1093/oxfordjournals.jpart. a037242.

Morris, L. (2010). Asylum, welfare and the cosmopolitan ideal. A Sociology of Rights. Abingdon: Routledge.

Mosley, L. (2013). "Just talk to people"? Interviews in contemporary political science. In L. Mosley (Ed.), Interview research in political science, (pp. 1-28). Ithaca: Cornell University Press.

Nimführ, S., \& Sesay, B. (2019). Lost in limbo? Navigating (im)mobilities and practices of appropriation of non-deportable refugees in the Mediterranean area. Comparative Migration Studies, 7(26), 1-19.

OECD (2017). Nach der Flucht: Der Weg in die Arbeit [After flight: The path into work]. Paris: Arbeitsmarktintegration von Flüchtlingen in Deutschland [Labour market integration of refugees in Germany].

OED Online (2019). Ambiguity, $n$ Retrieved June 21, 2019, from https://www.oed.com/view/Entry/6144?redirectedFrom= ambiguity\&.

Pratt, A. (2005). Securing Borders: Detention and deportation in Canada. Vancouver: University of British Columbia Press.

Pratt, A. (2010). Between a hunch and a hard place: Making suspicion reasonable at the Canadian border. Social and Legal Studies, 19(4), 461-480. https://doi.org/10.1177/0964663910378434.

Röder, S., \& Wittmann, P. (2017). Aktuelle Rechtsfragen der Ausbildungsduldung [Current legal questions on the vocational toleration]. Zeitschrift Für Ausländerrecht ZAR, 37(9), 345-352.

Rosenberger, S., \& Koppes, S. (2018). Claiming control: Cooperation with return as a condition for social benefits in Austria and the Netherlands. Comparative Migration Studies, 6(26), 1-18.

Rosenberger, S., \& Küffner, C. (2016). After the deportation gap: Non-removed persons and their pathways to social rights. In R. Hsu, \& C. Reinprecht (Eds.), Migration and integration: New models for mobility and coexistence, (pp. 137-150). Vienna: Vienna University Press.

Rubin, H. J., \& Rubin, I. (2012). Qualitative Interviewing: The Art of Hearing Data (2nd editio). Thousand Oaks: Sage.

Rutz, S., \& du Bont, A. (2020). Organized discretion. In T. Evans, \& P. Hupe (Eds.), Discretion and the quest for controlled freedom, (pp. 279-294). Cham: Palgrave Macmillan. https://doi.org/10.1007/978-3-030-19566-3.

Sætren, H., \& Hupe, P. L. (2018). Policy implementation in an age of governance. In E. Ongaro, \& S. van Thiel (Eds.), The Palgrave handbook of public administration and Management in Europe, (pp. 553-575). Basingstoke: Palgrave Macmillan. https://doi.org/10.1057/978-1-137-55269-3_29.

Salter, M. B. (2007). Governmentalities of an airport: Heterotopia and confession. International Political Sociology, 1(1), 49-66. https://doi.org/10.1111/j.1749-5687.2007.00004.x.

Satzewich, V. (2013). Visa officers as gatekeepers of a State's Borders: The social determinants of discretion in spousal sponsorship cases in Canada. Journal of Ethnic and Migration Studies, 40(9), 1450-1469. https://doi.org/10.1080/1369183X. 2013.854162.

Schammann, H. (2015). Wenn Variationen den Alltag bestimmen. Unterschiede lokaler Politikgestaltung in der Leistungsgewährung für Asylsuchende [When variations determine daily life. Differences of local policy design regarding the granting of benefits to asylum seekers]. Zeitschrift Für Vergleichende Politikwissenschaft, 9(3), 161-182. https://doi.org/ 10.1007/s12286-015-0267-4.

Schammann, H. (2017). Eine meritokratische Wende? Arbeit und Leistung als neue Strukturprinzipien der deutschen Flüchtlingspolitik [A meritocratic shift? Work and performance as new structuring principles of German refugee policy]. Sozialer Fortschritt, 66, 741-757.

Scheel, S. (2017). Appropriating mobility and bordering Europe through romantic love: Unearthing the intricate intertwinement of border regimes and migratory practices. Migration Studies, 5(3), 389-408. https://doi.org/10.1093/ migration $/ \mathrm{mn} \times 047$.

Schreyer, F., \& Bauer, A. (2014). Regionally unequal participation - tolerated forced migrants and dual vocational training in Germany. Sozialer Fortschritt, 63(11), 285-292. https://doi.org/10.3790/sfo.63.11.285.

Schreyer, F., Bauer, A., \& Kohn, K.-H. P. (2015). In-company training of tolerated persons: A win for the labour market, an opportunity for young forced migrants. Nürnberg: IAB-Kurzbericht.

Statistik der Bundesagentur für Arbeit [Statistics of the Federal Employment Agency]. (2017). Zustimmungen und Ablehnungen für Asylbewerber und Geduldete nach Rechtsgrundlagen [Approvals and rejections for asylum seekers and tolerated persons according to legal basis]. Nürnberg: Berichtsjahr 2016.

SVR (2017). Chancen in der Krise: Zur Zukunft der Flüchtlingspolitik in Deutschland und Europa [Opportunities in Crisis: The Future of Refugee Policy in Germany and Europe]. Berlin: Jahresgutachten 2017.

Thym, D. (2016a). Integration Kraft Gesetzes? Grenzen und Inhalte des "Integrationsgesetzes" des Bundes [Integration by law? Limits and contents of the federal 'integration act']. ZAR, 36(8), 241-273.

Thym, D. (2016b). Stellungnahme zum Entwurf eines Integrationsgesetzes [Statement on the draft integration act]. Berlin: Deutscher Bundestag Ausschuss für Arbeit und Soziales Ausschussdrucksache [German Parliament Committee on Employment and Social Affairs] 18(11)681, 17.06.2016.

Valenta, M., \& Thorshaug, K. (2013). Restrictions on right to work for asylum seekers: The case of the Scandinavian countries, Great Britain and the Netherlands. International Journal on Minority and Group Rights, 20, 459-482. https://doi.org/10. $1163 / 15718 n 5-02003006$

Will, A.-K. (2018). On "genuine" and "illegitimate" refugees: New boundaries drawn by discriminatory legislation and practice in the field of humanitarian reception in Germany. Social Inclusion, 6(3), 172-189. https://doi.org/10.17645/si.v6i3.1506.

\section{Publisher's Note}

Springer Nature remains neutral with regard to jurisdictional claims in published maps and institutional affiliations. 